\title{
Türk Modernleşmesinin Kadın-Asker Sembolü Sabiha Gökçen Üzerine Bir Değerlendirme
}

\author{
DOI: 10.26466/opus.532089 \\ *
}

\section{Aysun Yaralı Akkaya $^{*}$}

* Dr.Öğr. Üyesi, Van Yüzüncü Yıl Üniversitesi, İktisadi ve İdari Bilimler Fakültesi, Van/Türkiye E-Posta: aysunyaraliakkaya@yyu.edu.tr

ORCID: $\underline{0000-0002-6829-4282}$

\section{Öz}

Bu çalışmanın amacı, Türk Modernleşmesinde kadına verilen sembolik temsiliyeti Cumhuriyet Türkiye'sinin, önemli bir ismi olan Sabiha Gökçen üzerinden değerlendirmektir. Sabiha Gökçen, Mustafa Kemal'in manevi kızı olarak Cumhuriyetin kuruluşundan sonra onun yanında bulunmuş ve onun gözetiminde yetişmiş bir Türk kızıdır. Mustafa Kemal'in yönlendirmesi ile eğitimlerini tamamlamış ve Türk havacılı̆̆ının yeni gelişme gösterdiği bir dönemde pilot olmayı seçmiştir. Sabiha Gökçen, daha önce hiçbir kadının tercih etmediği bir meslek olan havactlı̆̆ ve eril bir alan olan askerliği seçmiş olması ile Türk modernleşmesinin ilerici yönünü gösteren etkili bir figürdür. Çalışma bu ön kabulle, modernleşme projelerinde kadınlara verilen rolün erkek inşacılar tarafından belirlendiğini tartışıken, Sabiha Gökçen'in kamusal alanda görünürlü̆̆̈̈ ve bir kadın olarak üstlendiği kurucu misyonunu ele almaktadır. Kadınların modernleşme sürecinde yaşadıkları ile uluslaşan toplumların bu dönemdeki konumları arasında paralellikler söz konusudur. Bu nedenle Türk modernleşmesi Batı dışı bir modernlik deneyimi olarak kendine özgü bir özelliğe de sahiptir. Sabiha Gökçen elde ettiği başarılarn ile Türk Modernleşmesinin sadece sembolik bir kahramanı olarak kalmamış, bunun dışında modernleşme projesinin ilerlemeci yönünün göstereni olmuştur.

Anahtar Kelimeler: Türk modernleşmesi, Kadın, Sabiha Gökçen, Batıcılık 


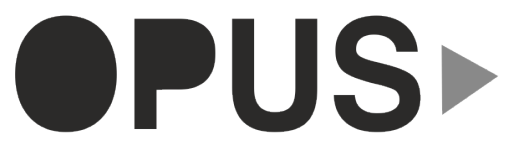

Uluslararası Toplum Araştırmaları Dergisi International Journal of Society Researches
E-ISSN : 2528-9535

YIl Year: 9

Cilt Volume: 11

Sayı Issue : 18

Haziran June 2019

Makalenin Geliş TarihiReceived Date:25/02/2019 Makalenin Kabul Tarihi Accepted Date: 20/04/2019

\title{
An Assessment on Sabiha Gökçen as the Female Military Symbol of Turkish Modernisation
}

$*$

\begin{abstract}
The aim of the present study is to assess the symbolic representation attributed in Turkish Modernisation to women on the basis of Sabiha Gökçen as a prominent figure in the Turkey of the Republic. Sabiha Gökçen was a woman of Turkey who had stayed with Mustafa Kemal as his foster daughter after the establishment of the Republic and been trained under his supervision. She completed her training under the guidance of Mustafa Kemal and chose to become a pilot in a period marked by the recent development of Turkish aviation. Sabiha Gökçen is an influential figure pointing out to the progressive aspect of Turkish modernisation by reason of her choice of aviation, which had not been preferred by any woman before, and of military as a masculine field for her profession. Based on this postulate, the study discusses the determinism of the role attributed to women in modernisation project by male constructors and addresses the public visibility of Sabiha Gökçen and the founding mission assumed by her as a woman. There are parallelisms between the experiences of women during the process of modernisation and the positions held by nations in the same period. Therefore, Turkish modernisation also bears a distinct character as a non-Western experience of modernity. Sabiha Gökçen, in this context, did not only remain as a symbolic heroine of Turkish modernisation, but also acted as an indicator for the progressive aspect of the modernisation project by reason of her achievements.
\end{abstract}

Keywords: Turkish modernisation, Woman, Sabiha Gökçen, Westernism. 


\section{Giriş}

Modernite, toplumunher alanında hızlı bir değişme süreci ortaya koyduğu gibi kadının da kamusal alanda daha çok görünür kılınmasını sağlamıştır. Batı kökenli bir süreç olarak modernite, on yedinci yüzyılda Avrupa'da başlayan ve sonraları bütün dünyayı etkileyen, toplumsal yaşam başlangıçta olmak üzere pek çok alanda örgütlenme biçimlerine işaret eder (Giddens, 1994, s.11). Özellikle zaman ve mekan bağlamında epistemolojik bir değişimi gerektiren modernite Batı dışı toplumlarda modernleşme projesi olarak gerçekleşmiştir. Modernleşme olgusunu sosyolojik olarak incelediğimizde Batılı literatürde, sıklıkla cemaatten, cemiyete geçiş şeklinde ele alınırken, Türkçe literatürde geleneksel yapılardan, modern toplumlara dönüşme olarak da ifade edilir. Modernleşme böylece geleneksel olandan moderne dönüşümü yani toplumsal, siyasal, ekonomik, dinsel ve bilimsel olarak her alanda değişimi ifade etmektedir (Çiçek vd., 2015, s. 272). ${ }^{1}$ Modernitenin kendisi bazı kavramları da beraberinde getirmiş bunların tanımlanması gereği doğmuştur. Bunların başında, modernizm ve modernleşme gelir. İlk önce modernizmden başlarsak, modernitenin anlatıldığı kapsamlı ve karmaşık söylemi ifade etmek için kullanıldığ1 görülmektedir. Modernizm belli değer yargılarını ifade edecek şekilde, içinde bilimcilik ve pozitivizmi, teknosantrizmi, akılcılık ve evrenselcilik gibi öğeleri barındıran bir kavramdır (Şaylan, 2002, s.102). Modernleşme ise modernitenin günlük hayata, sanat, tüketim toplumu ürünleri, yeni teknolojiler, yeni ulaşım ve iletişim tarzlarının girmesi, yeni bir endüstriyel sömürgeci dünya kurulması şeklindeki müdahalesinde bu dinamikleri belirlemek için kullanılır. Modernleşme ile toplumda bilim ve teknoloji aracılığıyla değişim, sosyal mobilitenin artması ve uzman rollere geçiş ve böylece sosyal farklılaşma yaşanacaktır (Best-Kellner, 1998, s.15). Abel Jeanniere modernizme geçişi dört olgunun belirlediğini ifade eder. Bunlar; bilimsel, siyasal, kültürel ve teknik olgulardır (Jeanniere, 2000, s.96). Modernleşme; öz olarak sosyalizm, liberalizm, kapitalizm gibi ideolojiler üreten, bireyselleşme, biçimleme, sanayileşme, sekülerleşme,

\footnotetext{
${ }^{1}$ Batı literatüründe oldukça geniş bir çalışma alanı sunmakta olan modernite ve modernite eleştirileri, öncelikle sosyoloji kuramcılarının tartıştığı konular arasındadır. Ferdinand Tönnies'in gemienschaft-gesselschaft kavramları, Emile Durkheim'da mekanik ve organik toplum kavramları buna örnek olarak verilebilir (Çiçek vd., 2015, ss.272).
} 
endüstrileşme, kültürel farklılaşma, ticarileşme, ekonomik ilişkilerin metalaşması, şeyleşme, kapitalizmin yükselişi, kentleşme, bürokratikleşme, rasyonelleşme, sosyal işbölümünün büyümesi, bilimsel düşünce tarzlarının yükselişi, iletişim tarzlarının dönüşümü ve nihayet demokratikleşme süreçlerini anlatan bir terimdir (Best-Kellner, 1998, s.15).

$\mathrm{Bu}$ anlamda çalışmanın ana eksenini oluşturan tartışma, Türk modernleşmesi projesi, temelde Batı merkezli moderniteyi gerçekleştiebilme hedefine dayanır.. Modernleşmeci görüş, çevre medeniyetlerin tarih sahnesinden yok olmamaları ve varlıklarını devam ettirebilmeleri için yegâne koşulun modernleşme sürecine adapte olmaları ve modernleşmek için Batı medeniyetini örnek almaları gerektiği anlayışına dayanmaktadır (Çiçek vd., 2015, s. 272). Bu bağlamda Türk modernleşme projesini, anlamaya ve açıklamaya yönelik çalışmalarda, üzerinde durulan temel iki eğilim söz konusudur. Bunlardan birincisi, Türk modernleşmesinin moderniteyi yeterince anlayamadığı ve aynı zamanda geriden takip ettiği tezidir. Bu nedenle daha çok batıcı söylemlere odaklanmış pozitivist, aydınlanmacı bir pozisyon oluşturulmuştur. Diğer bir yaklaşım ise Türk modernleşmesinin batı dişı modernleşme süreçlerine doğrudan bir rol model olduğu ve önemli bir özgünlük ve kendiliğindenlik içeren bir konuma sahip olduğu şeklindeki yaklaşımdır. Temel olarak iki kutba ve bu bağlamda da Türkiye tarihinin iki ayrı siyasal yaklaşımına tekabül eden bu bakış açısına karşılık, her iki yaklaşımın da tartışmasına katkı sağlayan daha gri tonlar diyebileceğimiz bakış açıları da mevcuttur. Ancak çalışmanın amacı, süreklilik arz eden bu bakış açılarına bitmeyen yeni tartışmalar eklemek değildir. Temel olan sorunsal, bu süreç içerisinde kadına verilen rol ve modernleşme projesinin Türk kadını üzerinde nasıl bir etki yarattığını açıklamaktır. Türkiye'de kadının modernleşme ile birlikte birçok açıdan daha göz önünde olan ve daha çok kamusal görünürlük mücadelesi veren bir kesim olduğunu söylemek mümkündür. Cumhuriyetin ilanı ile birlikte de bu görünürlük yasallık ile birleşerek meşruiyet kazanmıştır. Öncelikle kazanılan haklar ve sonrasında yeni devletin doğrudan cinsiyet temelli politikaları, kadının özgürleşmesi olarak tanımlanırken, kadınlar aynı zamanda ideolojinin taşıyıcısı ve rehberleri haline dönüşmüştür. Özellikle Cumhuriyetin ilanından sonra kadınlar Cumhuriyetin ilerici, batılı ve modernleşmeci konumunu öne çıkaran bir rol üstlenerek Cumhuriyetin modern yüzü olmuş ve savunucusu haline gelmiştir. Böylelikle kadınlar yeni 
Cumhuriyetin ilericiliğinin birer sembolü olarak belirginleşmiş ve hemen hemen her alanda kadının kamusal görünürlüğünü desteklemek amaçlı olarak sembol isimler oluşturulmaya çalışılmıştır. Sabiha Gökçen, işte bu sembol isimler arasında Cumhuriyete bağlılığı ile kendini ispatlamış aynı zamanda Cumhuriyetin ilerlemeci yönünü göstermek açısından oldukça radikal bir alanda kendini ispatlamış bir kadın olarak öne çıkmıştır. Çalışmanın üzerinde durduğu nokta ise Sabiha Gökçen'in doğrudan Cumhuriyetin ilerlemeci ve batıcı yüzünün önemli bir simgesi olmasının yanı sıra o zamana kadar yapılmayan bir işe girişmiş ve modernleşmiş bir ülkenin gelebileceği en hızlı noktanın simgesi haline dönüşmesidir. Bununla birlikte, Türk modernleşmesinin kendine özgünlügünün bir vurgusu olarak da karşımıza çıkmaktadır. Onun dünyanın ilk kadın savaş pilotu olması, modernitenin beşiği olan Batı toplumlarında ve Batı dışı modernleşme projelerinde görülmeyen bir başarıdır.

\section{Kendine Özgünlük ve Batıcılık Arasında Türk Modernleşmesi}

Modernleşme ve batıcılık, siyasal kültürümüzün belirgin kurucu öğeleridir. Bu nedenle, Türk modernleşme serüveninden bahsetmek aynı şekilde Türkiye'de siyasi kültürün temel özelliklerini de tespit etmek demektir. Özellikle Batıcılık, Osmanlı İmparatorluğu'nun son döneminden başlayıp Cumhuriyet Türkiyesi'ne yeni boyutlar kazanarak uzanan, Batı Avrupa'nın hem fikirsel hem de toplumsal yapısına ulaşılması gerektiğini savunan bir yaklaşımdır (Mardin, 1991, s. 65). Bir proje olarak modernleşme Batı dışı toplumlar ve coğrafi olarak daha doğuda olan toplumlar için batılılaşma olarak algılanırken, Doğu için kendinden farklı özelliklere sahip Batı'nın hedeflenmesi, bir kimlik değişimidir. Bu nedenle modernleşme, Batılılaşma ile eş anlamlı olarak kabul edilmiştir (Tekeli, 2002, s. 23). Burada yine yukarıdan yaptığımız kavramsal ayrımın üzerinden gidilebilir. Batılı olup olmama durumuna göre modernitenin anlamı farkl1lık göstermiştir. Bu açıdan batılı olanlar moderniteyi hem bir proje hem de kurumsal alt yapısıyla gerçekleştirirken batılı olmayan toplumlarda ise modernizasyon hayata geçmiştir. Modernite bireyi ve sınıfları kendi kimliklerinde eğitirken modernizasyon ise bu eğitimimin altyapısını oluşturmuş ve bu bağlamda Batı dışı toplumlarda farklı seyretmiştir. Batılı olmayan toplumlarda tarihsel evrim açısından bakıldığında batı ile aynı süreci 
yaşanmadığından, yaşanılan modern pratikler, çağdaş değildir. Batılılaşma ise işte bu gecikmeyi telafi edici bir araç olarak değerlendirilmiştir (Çiğdem, 2002, s. 69). Türk modernleşmesinin batılı olmayan ama batı ile temas halinde seyrettiğini söylemek yanlış olmayacaktır. Batı dışında modernlik geliştiren toplumlarda ortak deneyimler ve tarihsellikler söz konusudur. Aynı zamanda bu toplumları gruplandırdığımızda şunu görmekteyiz ki bu toplumlarda ya istekli ya da istenç dışı bir modernizasyon gerçekleşmiştir (Göle, 1998, s. 68). Ancak, bu durum modernitenin batı d1şındaki toplumlarca hedef alınmasını ve böylece onlar tarafından yeniden üretilmesini de sağlamıştır. Çünkü Nilüfer Göle'nin de belirttiği gibi “modernite tüketim düzeyinde, yaşam tarzında veya kültürel eserlerde hep ulaşılacak, öykünülen bir şeydir; yaşamakta olan, tüketilen, keşfedilen değildir" (1998, s. 65). Aynı zamanda bu durumun başka bir sonucu da modernliğin batının tekelinden çıkması ve alternatif modernlik anlayışlarının türemesidir (Göle, 1998, s. 66). Batı dışındaki ülkelerde modernite algılayışı değerlendirilirken de aslında buradaki konumlandırmanın, yani modernite ilişkisinin yine de batı temelinde olduğunu unutmamak gerekir. Dolayısıyla, elimizde batı modernliği modeli vardır ve bunun üzerinden modernlik yeniden üretilmektedir (Göle, 1998, s.67). Türk modernleşme serüveni de batı dışı modernlik şeklinde ortaya çıkan, ancak yeniden üretilen ve yukarıda ifade edilen alanlarda özgünlükler taşıyan bir yapıya sahiptir.

Türk modernleşme süreci ele alınırken, farklı dönemler halinde incelemek adetten olmuştur. Şerif Mardin, Hasan Bülent Kahraman gibi isimler, Batıcılık ya da Batılılaşmayı temel alarak modernleşmeyi evreler halinde ele almakta ve tartışmaktadırlar. Mardin, Batıcılığı Batı'yı her alanda örnek almak istemek olarak tanımlarken, ilk evrenin Osmanlı İmparatorluğu'nu düzeltme çabaları olarak anılan döneme denk geldiğini belirtmektedir (Mardin, 1991, s.11-12). Bu dönemde Osmanlı'nın düştüğü durum askeri alan başta olmak üzere pek çok alanda düzenlenmeler ile aşılmaya çalışılmıştır. Mardin, kronolojik olarak Batılılaşma süreçlerini ele alırken Atatürk dönemi ve sonrası süreci özellikle öne çıkarmıştır (Mardin, 1991, s. 19-20). Daha çok nasıl Batılılaşamadığımızın, nerede problemlerin ortaya çıktığını tartıştığı metninde Mardin, Batılılaşmayı taklit etme olarak tanımlarken yine de kendine özgü bir hale dönüştüğünü ifade eder. Bir diğer tasnif ise Hasan Bülent Kahraman'ın batılılaşmacı moderniteyi 
çeşitli dönemlerde ele alarak tartıştığı ayrımdır. Buna göre, Türk modernleşmesini başlıca üç evrede incelemektedir. İlk dönem teknik bilgi aktarımına dayalı bir modernleşme, ikinci dönem kurumsallaşmış bir modernleşme ve son dönemde de melezleşmiş bir modernleşmeden bahseder (Kahraman, 2002, s. 127). Kahraman'a göre ilk evre olarak kabul edilecek olan Osmanlı batılılaşması, doğrudan bir zihniyet sürecidir. Bu evre için asıl olan bilgi alımıdır. Dolayısıyla nötr bir anlam taşır ve doğrudan teknoloji ile sınırlı bir batılılaşma sürecidir. Batı her anlamda örnek alınırken, teknik altyapı ve askeri alandaki gelişmeler ile Osmanlı'nın ilerlemesi hedeflenir. Batılı ülkelere eğitim amaçlı olarak uzmanların gönderildiği ve elçiliklerin kurulması da bu dönemdedir (Kahraman, 2002, s. 126-128). Düşünsel olarak bu dönemde batılı dünyayı anlama çabası hâkimdir. Osmanlı bürokrasisi ve entelijensiyasının zihinsel olarak ulaşmak istediği işte bu Batı aydınlanması olmuştur. Bu fikri etkilenme "kameralizm"' olarak da tanımlanabilir. Aslında Batıdaki otoritelerin, halkın mülkiyetini koruma ve böylece bir milli devlet yaratma düşüncesi Osmanlıyı da etkilemiştir (Mardin, 1991, s. 14).

İkinci evre ise Erken Cumhuriyet olarak tanımlanan ve Cumhuriyetin ilanı ile yeni bir ulus-devlet yaratma arasında geçen süreci ifade etmek için adlandırılan dönemdir. Bu dönemde, Osmanlıdan kalan emperyal anlayışın ancak sınırlı bir şekilde dönüştüğünü görmekteyiz. Cumhuriyet projesinin hayata geçirilmesi ile birlikte geçmişten özellikle kültürel anlamda radikal bir kopma söz konusu olmuş, öte yandan paradoksal biçimde geçmişten kalan pek çok sorun da devam etmiş ve giderek büyümüştür. Cumhuriyet projesi temelde, oldukça elitist bir yaklaşım ortaya koymaktadır (Mutman, 2004, ss. 201). Aslında Cumhuriyet entelijansiyas1 bu anlamda Osmanlı'dan farklı değildir. Kuşkusuz ki; Cumhuriyet' in batılılaşma mantığı Aydınlanma projesi etrafında şekillenmiştir (Yavuz, 1998, s. 101). Cumhuriyetin ilk dönemlerinde batıcılık kurumsallaşmış, Kemalizmin hedefi olarak muasırlaşma yolundaki Türk toplumunun amacı Batı'nın sahip olduğu evrensel, soyut değerlere ulaşmak olarak belirlenmiştir. Bu çaba sadece siyasal alanda değil toplumsal alanda da kendini göstermiştir. Bu dönem Türk modernleşmesi Kemalist çağdaşlaşma

${ }^{2}$ Kameralizm, Batı'da fizyokratlar olarak bilinen bir kamu idaresi kuramcılarının uzantısıdır. Aydın despotizmi olarak da ifade edilen siyasal görüşün siyasal teorisine verilen addır (Mardin, 2002, ss. 83). 
istencini bir modernite projesi olarak tanımlar ve bu projenin Osmanliyla ilişkisini bir süreklilik ya da kırılma şeklinde değil de süreklilikle kırılmanın eşzamanlı olarak yaşandığı bir değişim/dönüşüm projesi olarak ele alır (Keyman, 2001, s. 16). Ancak Türk modernleşmesini, Osmanlı Türk modernleşmesi ve Kemalist Türk modernleşmesi olarak tasnif etmek daha yararlı olacaktır. Çünkü modernleşme Batı kaynaklı bir kavrama olarak süreklilik arz etmiş ve her ne kadar Türk modernleşme süreci Cumhuriyet ile birlikte bir kesintiye uğrasa da devamlılık sağlanmış, aynı modernite anlayışının radikal uygulamaları ve Kemalist reformlarla kurumsallaşması söz konusu olmuştur.

Modernleşme sürecinin üçüncü evresinde, modernleşme ile birlikte batılılaşma birbirini tamamlayıcı unsurlar halini almış ve kendine somutlaştırıcı unsurlar bulmuştur. İşte bu dönem için bir melezleşme olduğu görüşü ağırlık kazanmıştır (Kahraman, 2002, s. 135). Bu dönemi daha çok 1923 sonrası zaman olarak değerlendirdiğimizde, dikkati çeken konu homojen bir dönem olmadığıdır. 1950'den sonra önemli kopmalarla karşılaşılmıştır. Bütün bu ara dönemlerden her biri tek başına değil genelde birbiri ile etkileşim halindedir. 1950 tarihi önemli dönüm noktası olarak ele alınmasında, bu dönemde o zamana kadar birlikte hareket eden siyasal iktidar ve kültürel iktidarın kopmasıdır. Yani o döneme kadar resmi ideoloji tarafından belirlenen bir batılılaşma çabası ve onun toplumsallaştırıcı etkisiyle Türk modernleşmesi biçimlendirilmiştir. Bu biçimlendirme ifade ettiğimiz gibi bir zihniyet yaratma çabasıyla, eğitim kurumları aracılığıyla oluşan bir ideoloji aktarımıdır. Böylece elitle dayanışma sağlanarak modernleşme kültürel projesini kurmuştur. İşte bu durum 1950 sonrasında siyasal iktidarın kaymasıyla halk kültürü ve siyasal kültür arasında kopukluk yaşanmasına neden olmuştur. Artık çevredeki kültür siyasal iktidarın dayanağı olmuş, kurucu ideoloji terkedilmiştir. Onun baskıcı homojenleştirici öğelerinden de vazgeçilmiştir. 1950'lerden sonra görülen gündelik hayatın çok daha farklılaştığı bir kültür anlayışıdır ve kendini bu şekilde üretmiştir. Bu dönemde kurucu ideolojinin kültürel anlamdaki Batılılaşma anlayışından vazgeçilse dahi Batıyla ekonomik ve sanayileşmeci anlamda bir bütünleşme hedefi devam etmiştir. BM ve NATO üyelikleri bu hedefin sonuçlarıdır. Bu açıdan bakıldığında siyasal kültürümüz içinde temel olabilecek sonuçları şu şekilde sıralamak mümkündür: Birincisi, 1950 sonrası Batılılaşma "Türk muhafazakâr modernleşmesini" 
meydana getirmiştir ${ }^{3}$. İkincisi bundan sonra artık modernleşme ve batıc1lık içselleştirilmiştir. Üçüncü olarak da bu içselleştirmeden dolayı da tam anlamıyla bir "melezleşme" durumu oluşmuştur (Kahraman, 2002, s. 135136).

Türk modernleşmesi sonuç olarak, süreklilik ile birlikte kopuşu içeren, yeni bir devleti kuruluşunu içinde barındıran sosyal, siyasal ve kültürel alanda toptancı bir değişimi içermektedir. Cumhuriyetin oluşumu ile Kemalist projenin uygulamaları çok önemli bir kırılma döneminin göstergeleridir. Bu uygulamalar nedeni ile Cumhuriyet sonrasında ise önceki dönemden kopuş göstermiştir.. Osmanlının son döneminden başlayarak gelişen batılılaşma çabaları, çöküşü durdurabilmek için girişilen düzenleme faaliyetleri, batıyı teknik olarak yakalayabilecek bir düzeye gelebilmek ve tekniği alırken, kültürümüzü yok etmemeyi hedeflemiştir. Bu anlamda muhafazakâr modernleşme, Cumhuriyet dönemiyle birlikte radikalleşmiş, Cumhuriyet dönemi ile birlikte batılılaşma politikasında egemen olan unsur kültürel anlamda bir batılılaşma politikasının gerçekleştirilmesi olmuştur. Batılılaşma yeni kurulan ulus-devlet için ileri hedef olarak temel alınmış, böylece devlet eliyle tepeden aşağıya alınan radikal kararlar uygulamaya geçirilmiştir.

\section{Türkiye'de Kadının Modernleşme Deneyimleri: İttifaklar, İtilaflar}

Türk modernleşmesinin temelde cinsiyet üzerinden şekillenen politikalar ile birlikte, toplumsal alanda etkili olduğu ve karşılık bulduğunu söylemek mümkündür. Modernleşme ile birlikte toplumsal alanda yaşanan değişimi en iyi gösteren örnekler ise dönemin edebi, sanatsal ve kültürel pratikleridir. Dönemin roman, dergi ve gazeteleri üzerinden kadın ve erkeğin konumu, modernleşme sürecindeki durumları okunabilir. Özellikle "üst sınıf erkeklerinin aşırı batılılaşması" üzerinde çokça vurgu yapılır. Recaizade Ekrem'in, Bihruz Bey tiplemesi aşırı batılılaşmanın en iyi göstergelerinden biridir. Bihruz Bey'de tiplemesinde, sosyal bir gerilim göze çarpmaktadır (Mardin, 2002, s. 42). Bunda halk arasındaki bölünmenin gittikçe belirginleşmesi etkilidir. Müslüman ve Avrupalı kesim arasında, mahalle

\footnotetext{
${ }^{3}$ Muhafazakâr modernlik kavramı ve Türk modernleşmesine etkisi için Nazım Irem'in "Muhafazakâr modernlik, "Diğer Batı" ve Türkiye'de Bergsonculuk" makalesine bakılabilir.
} 
yaşantılarında bile değişebilen bir ayrım söz konusudur. Bu ayrım, aynı zamanda yöneten yönetilenler arasında da yaşanmaktadır. Aşırı batıl1laşma ile lüks yaşantıya düşen üst sınıf, halk tarafından eleştirilir. Üst sınıf için modernlikten kastedilen tüketime yönelik ve bunu artırıcı şeylerdir denilebilir. İşte batılı gözükmek uğruna aşırı tüketim gerçekleştiren bu kesim, sıradan halkın düşmanlığını da kazanmıştır. Temel olarak bakılacak olursa zenginlik ve gösterişli yaşam Türk kültürü içerisinde hoş karşılanmamaktadır. Tüketimin öne çıkarılması, halk için modernleşmenin masraf çoğaltıcı biçimde tanımlanmasına neden olmuştur. Örneğin Adalet Ağaoğlu'nun (1998) “Ölmeye Yatmak" kitabında da ifade edildiği gibi çocukların okula gönderilmesi ile yeni yaşantının etkileri hissedilmeye başlanmıştır. Yani eski "yeniden üleşime” dayalı anlayış kalkmıştır. Ganimetin her savaş sonrasında dağıtıldığı ve şehirlere göçen halkın kendine yeniden bir hayat belirlediği sistem yoktur artık. Bu dönemde bürokratik etkinliğin de artışıla hem şehirde hem de taşrada zenginliğin etkisiyle iki farklı yaşantı ortaya çıkmıştır. Halk bu ayrımın farkındadır ve küçümsendiğini bilir (Ağaoğlu, 1998). Özellikle Osmanlı dönemi modernleşmesinde devlet ve birey arasında sağlam yapılar oluşturulmadığı için toplumun devletle ilişkileri üzerinden bir sosyalleşme gerçekleşir. Ancak diğer taraftan devlet dışında da ayrı bir sosyalleşme alanı doğmuştur. Bu durumda Osmanlı'da, dinsel örgütlenmeye bağlı ve daha çok devletin etkin olduğu cemaatçi bir yapı oluşmuştur. Yine dönemin romanlarında, kadınların durumu da hiciv edilmiştir. Aşırı batılılaşmanın kadınların yaşantısındaki etkisi eleştirilmiştir. Kadınlar modernleşmenin en iyi gösterenidir. Modernleşmenin kadınların özgürlük alanını genişletmesi, diğer taraftan ise kadınların sınırlarını aşabilme ihtimali, her zaman en çok sorgulanan unsur olmuştur. Kadının özgürleşme hareketleri ahlaki bir çöküntü olarak değerlendirilmiştir. Bundan da sorumlu tutulan batılılaşmadır. Ağaoğlu'nun kadın kahramanı olan Aysel'de kendi içinde hep bu çelişki arasında kalmıştır. Çocukluğunda resmi ideolojinin etkinliğiyle kasabasında batıcı bir eğitim alan kahraman, şehirde de kendine model olarak Atatürkçü düşünceyi almış ve bu doğrultuda bir yaşantı çizmiştir. Ancak tam anlamıyla özgürleşememiştir (Ağaoğlu, 1998). Modernleşmenin vaat ettikleri, Aysel'in yaşamında kendi kurallarıyla hayatını yeniden kısıtlamıştır. Dolayısıyla, batılı tipte modernleşen kadınlar hem Osmanlı da hem de Cumhuriyet döneminde kendi iffet ve namusları açısından 
sorgulanmıştır. Bu düşünceden dolayı gerek Osmanlı' da gerekse Cumhuriyet dönemindeki reform çalışmalarında yaşanan en ufak bir tehdit anında, kadın haklarıyla ilgili düzenlemeler durdurulmuştur.

Modernite, iki temel vurgu üzerinden toplumda hızlı bir değişim yaratmıştır. Bunlardan ilki modern birey bir diğeri ise seküler toplum olgusudur. Her iki ana parametre de kadınların geleneksel toplumdan çıkışı ve modern bir toplumda kendine yer edinmesi adına önemlidir. Birey bilinci ile kadınlar kendi özgürlüklerine temel haklar bağlamında sahip olurken, modern devletin eşit vatandaşları haline dönüşmüşlerdir. Bu nedenle modernleşme sürecinde edinilen haklar ve bu hakların kadınlara neler getirdiğini analiz etmek önemlidir. Osmanlı' nın son dönemlerinde, kadınların pozisyonlarını belirleyen en önemli gelişmeler, üst sınıf, devlet ya da saray yöneticisi ailenin kadınlarının kurdukları ittifaklarda kendini göstermiştir. On dokuzuncu yüzyıl ortalarında kurulan kadın haklarını savunan dernekler ve dergiler bu ittifakın örnekleridir: Türk Kadınlar Birliği, Terakki Gazetesi, Hanımlara Mahsus Gazete gibi. Dönemin önemli isimleri ise, Şair Nigar, Fatma Aliye, Halide Edip, Nezihe Muhiddin ve Emine Semiye'dir (Sancar, 2014, s. 93). Aslında modernizmin kadınların toplumsal konumuna ya da yaşam alanlarına doğrudan müdahale gibi bir amacı yoktur ancak modernizmin getirdiği yeni yaşam biçimi ve düşünsel etkiler dünyayı algılama başta olmak üzere kadınların yaşamlarını dönüştürmüştür (Kaypak, 2014, s. 64). Dolayısıyla Osmanlı'nın son dönemi ile birlikte kurulan bu dernekler ve onların kurucusu olan önemli isimlerin, Milli Mücadeleye destek verdiklerini, sonrasında da yeni ulus-devletin şekillenmesinde rol oynamak istediklerinigörmekteyiz. Ancak Türk modernleşmesi sürecinde erkekler modernleşmenin getirdiği fırsatlardan yararlanmasına karşılık, kadınlar engellenmiştir. Bu durumu erkekler de pek çok defalar kabul etmişler, reformların hayata geçirilmesi için onlarla birlikte hareket eden kadınlara ihtiyaç duyduklarını vurgulamışlardır (Sancar, 2014, s. 93). Aynı zamanda reddedilen Osmanlı mirası içerisinde kadının konumu ikincilken yeni devletin milliyetçi söylemi, Türk geleneklerinin kadın ve erkeğin toplumsal alanda eşitleyen geçmişine de sıkı s1kıya bağlı kalma amacını taşımakta idi. İşte yeni kurulan devletin eşit haklar ile donatmayı vaat ettiği kadınlardan beklentisi, onlara sunulan seçkin konumlarına karşılık rejime sadakat ile bağlı kalmalarıdır (Tekeli, 2011, s.29). Ancak sadece Türkiye örneği değil diğer Müslüman ülkelerde 
kadınların haklarını elde etme mücadelesi devletin aldığı konuma göre farklılaşabilmektedir. Türkiye'de kadın hareketinin yokluğunda politik olarak öncülük etmek için yapılan reformlar hem sınırlı hem de potansiyele sahiptir. Bu reformların varlığı, hakların kazanılması ile özgürlük arasında kalmış olup, kadınların yapısal sorunlarına ise hiç değinmemiştir. Bu durumda Türkiyeli kadınların kurtulmuş ama özgürleşmemiş olduğunu söylemek mümkündür (Kandiyoti, 1997, s.72). Özellikle Erken Cumhuriyet döneminde kadınların erkeklerle eşit fırsat talepleri karşılanmamış, bu talepler kurucu eril tahakkümün baskısı ile şekillenmiş ve hatta yasaklanmıştır. ${ }^{4}$ Bunun yerine yapılmaya çalışılan, Türk kadın kimliğinin eşit vatandaşlık statüsünden çok Türk milli ve modern kimliğini dünyaya gösteren bir kültür göstergesi ve kültür farklarının sınırlarını temsil eden sembolü olması şeklindendir (Sancar, 2014, s. 112). Mustafa Kemal'de CHF kongresindeki söylevinde dile getirdiği gibi kadınlardan beklenti, milletin evlatlarını yetiştirmeleri ve ailenin devamlılığını sağlamalardır. İş yaşamında ise kadının varlığı ancak erkeklerin çizdiği sınırlar içerisinde mümkün olacaktır. Yani kamusal alanda kadınlar her meslekte değil sadece onlara uygun bulunan alanlarda görünebileceklerdir. Dolayısıyla modernleşme ile birlikte şekillendirilen eril ve dişil mekânlar, yeni kurumlar yaratmıştır. Örneğin; Ordu, siyasi partiler, parlamento gibi kurumlar tek cinsiyetlidir (Sancar, 2014, s. 155-157). Böylece, Türk modernleşme projesi içerisinde ataerkil toplumsal yapının getirdikleri adeta korunmaya çalışılarak, kadınların özerklikleri kontrollü gerçekleştirilmiştir. Kadınların kontrolünün en önemli gerekçesi, kadının cinsel iffeti ile aile ya da sülale şerefi arasında kurulan bağlantıdır. Kadınların yapacağı yanlışlıklar, bütünü ile bu topluluklara utanç ya da şerefsizlik getirebilir. Bu nedenle kadınlar kamusal alana geçmeleri ile evdeki kontrolün ortadan kalkması sonucunda yeni denetim mekanizmaları gerekecektir (Kandiyoti, 1997,s.74). Aslında, modernlik sadece kadınlar ya da erkekler arasında değil aynı zamanda cinselliğe dayalı düzenleme rejimlerinde de denetim alanları yaratmıştır. Modernlik ile birlikte homoseksüellik dışlanırken, heteroseksüellik kayıt içinde düzenlenmeye çalışılmıştır. Böylece

\footnotetext{
${ }^{4} 1923$ yılında Nezihe Muhittin başkanlığında kurulan Kadınlar Halk Fırkası, sonrasında Türk Kadınlar Birliği şeklinde 1925'de kurulmuş ve kadın hakları mücadelesine devam etmiştir. Örgüt, 1935 yılında kadınlara siyasal hakların verilmesinden sonra, hedeflerini gerçekleştiği gerekçesiyle kendi kendini feshetmiştir (Durakbaşa, 1998, ss. 39).
} 
modernlik cinselliği denetlemekte buna bağlı olarak beden rejimleri yaratmaktadır (Sancar, 2014, s. 25). Erkekler ve kadınların her biri için ayrı ayrı zevkler, arzular, estetik gibi duyguları güçlendiren ya da bunlara bağlı kalan mekânlar ve meslekler belirlemiştir. Öncelikle eril mekânlar olarak beliren bu yerlere kadınların girmesi sinırlandırılır ve bunun gerekçesi biyolojik cinsiyete dayandırılarak açıklanır. Bunların içerisinde askerlik ve ordu eril mekânlardır, çünkü buralar otorite, çatışma ve rekabetin desteklendiği alanlar olarak şekillendirilmiştir (Sancar, 2014, s. 25). Aslında modernleşme öncesinde de eril mekanlar belirlenmiştir. Askerlik hatta asker kişiler için kadınlar uzak durulması gerekilenler ler arasındadır. Örneğin Yeniçerilerde evlenme yasağı, onların savaşma yeteneğini k1sitlayabileceği düşüncesinden dolayı getirilmiştir. Sonuç olarak Türk modernleşme projesinin getirdiği düzenleyici ve radikal reformlar -ki bunlar daha çok laik politikalardır- kadın haklarını güçlendirmiş ve ilerleterek bir dönüşüm yaratmıştır (Kandiyoti, 1997,s.82). Sabiha Gökçen, Türk modernleşmesinin kadın üzerindeki bu ilerlemeci boyutunu gösteren önemli bir örnektir. Ancak çalışmada, bu ilerlemenin sembolik olduğu ve sınırlı kaldığı gösterilmeye çalışılmıştır.

\section{Sabiha Gökçen: Türk Modernleşmesinin Kadın-Asker Sembolü}

Türk modernleşmesi yarattığı dönüşüm kendine uygun yeni mekânlar ile birlikte yeni bir birey tipini de şekillendirmiştir. Makbul vatandaş ya da sadık bireyler, Cumhuriyetin bekçileri olarak sürekli olarak denetlenmekte ve disipline edilmektedirler. Cumhuriyet dönemi ile birlikte "kent ve kadın" değişimin yani batıcı anlamda ilerlemenin en çok gözlemlendiği alanlardır. Kent ve kadın bu anlamda yeni kurulan ulus-devletin sembolleridir. Modern kentler yeni Cumhuriyet'in tanitımını yaparken, kadınlar yeni devletin yüzleri olarak resmedilmektedirler (Kaypak, 2016, s. 34). Ayrıca modern toplumların kendisi doğrudan hiyerarşik ayırımlar yaratan ve bu alanda daha hızlı bir süreç yaşayan toplumlar oldukları için cinsiyet üzerinde de eşitsizliklerin daha belirgin bir hale bürünmesine neden olmuşlardır. Bu eşitsizlikler bir taraftan biyolojik farklılıkların bir sonucu gibi gösterilirken, modern toplumun kendisinin dayandığ bölümü ile de uyumlu olduğu görüşünü güçlendirmiştir. Dolayısıyla modern toplumun kadına ve erkeğe biçtiği rol, bundan sonraki süreçte 
toplumun ilerlemesi için de gereklidir. Örneğin, kadınlar için çocuk yetiştirmek, sahip oldukları duygusal ve sabırlı mizaçları ile örtüştürülmüş iken, askerlik bir erkeğin yapabileceği kuvvet isteyen bir meslek olarak resmedilmiştir (Sancar, 2014, s. 23). Cinsiyetin biyolojik temelli olarak kabul edildiği ulus-devlet modellerinde, modern toplumun çekirdek ailesi desteklenmiştir. Modern toplumun sürekliliğini sağlayan temel belirleyen yapıların güçlü bir şekilde varlığını sürdürebilmesidir. Bu nedenle aile toplumsal yapının en küçük birimi olarak, modern toplumu inşa eder. Çekirdek ailenin desteklenmesi ulus-devlet için aynı zamanda eril ve dişil kimliklerin sabitlenmesine olanak sağladığı gibi kadın ve erkeğin toplumdaki amacını da belirler (Giddens, 2008, s.246-247). Aile içerisinde erkekler para kazanmak ve ev dışı işlerin yapılmasından sorumlu tutulurken kadınlar ise ev içi işleri, çocuk bakımı gibi sorumlulukları yerine getirir. İşte yeni kurulan ulus-devletler, bu durumda özel alanda sorumluluğu olan kadınları kamusal alanda görünür olmalarının yolunu ancak onun kendine özgü meslekler edinmesi ile mümkün görmektedir. Bu nedenle kadınlar cinsiyet özelliklerine uygun mesleklere yönlendirilmiştir. Burada Jayawardena'ın da üzerinde durduğu gibi, ulus-devlet kuruluşlarında kadınların konumunun sınırlandırılması ile karşılaşıldığı söylenebilir. Jayawardena'a göre kadınların ulusal bağımsızlık hareketlerinde güçlendirici bir rolü vardır. Bu nedenle kadınlar, ulusal bağımsızlık mücadeleleri süreçlerinde milliyetçilikle işbirliği yapmaktadırlar. Dolayısıyla, kadın hareketlerinin talepleri ile milliyetçilik örtüşürken, bu birliktelik uzun vadede sürdürülememektedir. Kadınlar yeni kurulan ulusu temsil ederken, devletin kurulup galip gelmesinden sonra, kamusal alanda eşit vatandaşlik konumuna gelememektedirler (Sancar, 2014, s. 61). Bu nedenle sembolik olarak bu işbirliği ulus-devlet kuruluşundan sonra gerçekleşmiş gibi gösterilir. Çalışmada ele alınan Sabiha Gökçen ismi de bu sembolik kamusal görünürlügün örneklerinden biridir. Aslında kadınlar ile eril iktidarların ilişkileri dönemsel olarak farklılık gösterebilmektedir. Buna göre, Milli mücadelede verdikleri desteğe rağmen yeni ulus-devletin oluşumu ile sessizliğe yönlendirilen kadınlar içinde gözden düşenler vardır. Halide Edip, Latife Hanım, Nezihe Muhittin gibi isimler Cumhuriyetin kuruluşu ile birlikte hiçbir kurumda yer almamıştır. Kamusal alanda var olsalar bile görünürlükleri azdır. Diğer bir kadın tipi ise Cumhuriyet ile uyumlu kadınlardır. Afet İnan bu isimlerden en öne çıkanıdır. Milli mücadele 
dönemi kadınları yönetimin dışında tutulurken, onların yerini bu yeni uysal kadınlar almışve bu kadınlara modern eğitimler verilerek birer rol model olmaları sağlanmıştır. Afet İnan dışında bu yeni uyumlu kadınlara Atatürk'ün bizzat evlat edindiği kız çocukları da eklenebilir (Sancar, 2014, s. 168-175). Serpil Sancar yazısında Sabiha Gökçen üzerinde durmamıştır ancak o da Atatürk'ün evlat edindiklerinden ve sürekli onun himayesinde olan bir kadındır.

Sabiha Gökçen modern Türkiye Cumhuriyetinin ilk kadın pilotu ve ilk defa bir askeri harekâta katılması ile de ilk kadın savaş pilotudur. Dünyada da bu unvanı almış bir isimdir. Sabiha Gökçen, aslında yeni kurulan ulus-devletin modernleşme sürecini göstermesi açısından da bir rol model olmuş pek çok alanda ilkleri yaşatmıştır. Bununla birlikte onun deneyimleri Türk modernleşme projesinin geldiği noktayı göstermesi açısından da etkilidir. Özellikle askerlik ve ordu içerisinde Tanzimat ile başlatılan Batılılaşma serüveninin en ilerici hamlesidir. Sabiha Gökçen bir kadın asker olarak ordu gibi modernleşmenin etkisinin ilk hissedildiği alanda önemli bir başarı elde etmiştir. Bunun için aslında Osmanlıda bir hayal olan hedefi gerçekleştirilmiştir. Bu nedenle modernleştirici elitler için çizilmiş bu ilerlemeci yaklaşımın sembolüdür (Altınay, 2015, s. 275). ${ }^{5}$

Sabiha Gökçen'in hayatından kısaca bahsedecek olursak. Atatürk'ün küçük yaşta evlat edindiği ve yaşamının her noktasında destek verdiği manevi kızlarından biridir. Bursa' da doğmuş ve Mustafa Kemal ile Bursa gezisinde tanışmış,ona okumak isteğinden bahsetmiştir. Mustafa Kemal kendi çabası ile onunla tanışan bu kızın cesaretini takdir etmiş ve onun iyi bir tahsil alması için ailesinin izni ile onu evlat edinmiştir. Sabiha Gökçen "Atatürk ile Bir Ömür"6 isimli kitapta, bu teklifin onu çok heyecanlandırdığını anlatmıştır. Sabiha Gökçen, Atatürk tarafından evlat edinildikten

\footnotetext{
5 1913'de yayınlanan Kalem dergisinde yayınlanan bir karikatür "Geleceğin Türkiye"si olarak resmedilmiştir. Resimde çarşafı bir kadın istanbul'un üzerinde uçak kullanırken çizilmiştir. 50 yıl sonraki Türkiye diye aktarılan karikatürün yer aldığı dergi bir mizah dergisidir ama Yeşim Arat’a göre bu öngörü Cumhuriyetin ilk yıllarında Sabiha Gökçen tarafından yerine getirilmiştir. Sabiha Gökçen askeri kıyafetleri ile geleceğin Batılılaşmış, ilerici, laik, özgürlükçü Türk toplumunun bir göstergesi olmuştur (Arat, 1998, ss. 84,85).

6 Sabiha Gökçen'in 1981 kaleme alınan ve anılarından oluşan "Atatürk Ile Bir Ömür" kitabında ömrüm olarak anlattığı dönem 1924'den sonraki yaşamıdır. Kitapta Atatürk'ün ölümüne kadar geçirdiği yılları anlatır. Ondan sonrasından hiç söz etmez. Onun için yaşamanın en kıymetli dönemi bu yıllardır.
} 
sonra onun desteği ile Arnavutköy Kız Lisesi-Üsküdar Kız Liselerinde ve bir dönem de yurt dışında okur. Ancak Sabiha Gökçen'in geçirdiği rahatsızlıklardan dolayı eğitiminde hep aksamalar olmuştur. Bu dönemde hastalıklarının yanı sıra onu üzen Mustafa Kemal'den de uzak kalmaktır. Sabiha Gökçen anılarında, aile özlemini, memleket özlemini ifade ederek vurgular. Sonrasında Çankaya'da kaldığı yıllarda özel dersler ile eğitimini Atatürk'ün yönlendirmeleri ve desteği ile tamamlamıştır (Verel, 2000, s. 31-32). Sabiha Gökçen için yaşamında en çok istediği şey Atatürk'ün ona duyduğu güveni boşa çıkarmamaktır. Bu anlamda Atatürk, Sabiha Gökçen ile birlikte bütün Türk kızlarına duyduğu güveni ve yeni ulusun geleceğine yönelik hedefleri belirlemiştir: "Türk kadını tarlada, savaşta erkeğini aratmaz, ata binmede bile farksızdır, hatta silah kullanmada onları çok kere geride bırakır" (Verel, 2000, s. 36-57). Sabiha Gökçen'in havacı olması ve eril bir alana girmesinde Mustafa Kemal belirleyici olmuştur. Mustafa Kemal'in böylece hem yeni kurulan Cumhuriyetin ilerici ve reformist alandaki etkisini göstermek hem de yeni kurulan kurumlardan biri olan havacılığa kendi evlatlarından birinin dahil olmasını sağlayarak sahiplenmek istemektedir. Atatürk'ün manevi kızı olan Sabiha Gökçen, 1930'larda bizzat Cumhuriyet' in kurucu lideri Atatürk'ün, bir Türk kız1nın dünyadaki ilk kadın pilot olmasının ne kadar gurur verici bir olay olacağını söyleyerek istemesi ile pilotluk eğitimi almıştı (Altınay, 2013, s. 265). Türk havacilığının gelişmesi ve Türk Tayyare Cemiyet'inin oluşturulması Atatürk için güçlü bir devlet olmada atılması gereken adımlardan biridir. 1925'de kurulan Türk Tayyare Cemiyeti'nin ve sivil havacılığın gelişmesi ona göre aynı zamanda ulusun gelişmesiydi. Hatta bu kuruma pek çok finans kaynağı ayrılır. Böylece Atatürk, halkının sahip çıktığı bir devlet ve devlet kurumu yaratma gayretindedir. Mustafa Kemal' in ifadelerinde sıklıkla modernleşmenin teknik ve bilimde ilerlemek ile eş tutulduğu vurgulanmıştır. Örneğin, Türk kuşunun açlış töreninde Sabiha Gökçen'e "Havacı olmak ister misin" diye sorduğunda "Türk kadının da uçabileceğini herkese göstermek ister misin?" der. Mustafa Kemal'in böyle bir şeyi teşvik etmekteki gayesi, onun havacılık konusunda eğitmen olabilecek bir düzeye gelmesi ve yeni havacı gençler yetiştirmesidir. Mustafa Kemal'e göre böylece "istikbalin göklerde olduğuna inanan bir kuşak" da yetiştirilmiş olunacaktır (Verel, 2000, s. 98). Sabiha Gökçen, aldığ 1 eğitimlerden sonra Eskişehir Askeri Tayyare okulunda asker kadın pilot 
olarak göreve başlar. Eğitim sürecinde Sabiha Gökçen, birçok erkeğin içerisinde tek kadın olduğunu ancak bu durumun ona farklı davranılmasına sebep olmadığını ifade eder. Sabiha Gökçen aynı zamanda Atatürk'ün kızı olmasının da ona ayrıcalık yaratmadığını dile getirir. Dersim harekâtı ile ilgili yaşadığı anı bu konudaki ayrıcalığa itirazı ile ilgilidir.

"1937 ilkbaharında görev yaptığım Eskişehir Birinci Tayyare alayında bir hareketlilik olduğunu gördüm. Nedenini sordum ancak kimse cevap vermedi. Sonra Dersim harekâtından haberdar oldum. Alaydaki diğer erkek arkadaşlar görevli iken dâhil edilmediğgimi öğrendim. Alay komutanına bunun nedenini sordum. Komutan, bu önemli bir harekât ve sen bir kızsın, üstelik Atatürk'ün kızısın. Oraya gidip gitmemene biz karar veremeyiz" dedi (Verel, 2000, s.116).

Sabiha Gökçen devaminda, Ankara'ya gelir ve durumu Atatürk'e anlatır. Bu harekâtta görev almak istediğini ifade eder. Atatürk ise Fevzi Çakmak'a sormak gerektiğini, bunun bir askeri harekât olduğunu ve o izin verirse gidebileceğini söyler. Atatürk ayrıca, "Unutma sen bir kızsın, alacağın görev çok zorlu ve çok zor durumlarla karşı karşıya kalabilirsin. Eğer böyle bir durumla karşılaşırsan karşındakilere teslim olmak durumunda ne yapacaksın?" diye sorar. Sabiha Gökçen, beklenen cevabı verir, "ben kendimi onlara canlı olarak teslim etmem" der. Mustafa Kemal, Sabiha Gökçen'in bu tepkisine karşılık kendi kullandığı silahı ona verir ve "bu tabancayı sana haysiyetine ve şerefine dokunacak bir durumda kald1ğında kullanman için veriyorum" diye ekler. Böylece harekâta katılması onaylanır. Harekât sırasında Sabiha Gökçen beline Atatürk'ün ona verdiği silah ile katılır (Verel, 2000, s. 116). Mustafa Kemal, Sabiha Gökçen'in an1larında sıklıkla ulusal tarihimizin inşasında kadınların da erkekler kadar öne çıkaracak çabalar harcadığını ifade etmiş ve her zaman kadınlar ile birlikte yan yana savaştıklarını vurgulamıştır. Böylelikle söylemsel olarak kadın asker, bir yandan bir eşitlik perspektifi ile sunulurken, öte yandan zaman zaman kadının cephedeki varlığı, erkek egemen söylemin "namus" kavramı içerisinde sunulmakta ve farkında olmadan bu kavramın kendisini yeniden üretmesine olanak sağlanmaktadır. Sabiha Gökçen'in harekâta katılması eril bir alanda kadın olarak cinsiyet farkı gözetilmeden var olmasını sağlamıştır. Ancak diğer bir taraftan erkek ve kadın mekânlarının sınırları çizilmiştir. Erkekler askerlik mesleği ve zorunlu askerlik 
uygulamaları ile adeta yeni kurulan devlet ile bağlarını güçlendirirken, kadınların alanları sınırlar ile çizilmiştir. Sabiha Gökçen'e namusunu korumak için verilen silah örneğinde de görüldüğü gibi cinsiyet farkları ordu içerisindeki görevin yerine getirilmesi esnasında da öne çıkarılmıştır (Altınay, 2013, s. 290-291). Sabiha Gökçen, Dersim harekâtına katılması ile birlikte "dünyanın ilk kadın savaş pilotu" olarak anılmaya başlanır ve Cumhuriyet'in gurur duyduğu bir isim haline gelir. O kadar ki Atatürk, Gökçen'den katılacağı toplantılara askeri üniforması ile gelmesini istemekte, üniformalı fotoğrafları dönemin gazetelerini süslemektedir (Alt1nay, 2013, s. 276). Altınay'ın belirttiği gibi Sabiha Gökçen, Türk ulus-devletleşme süreci içerisindeki asker-ulus inşasında ilk asker kız olarak önemli ve ilktir. Gökçen, kadınların da pilotluk gibi oldukça zor bir mesleği layıkıyla yerine getirebileceğini ve bu açıdan Türk kadının başarılı olabileceğini tüm dünyaya göstermiştir (Altınay, 2013, s. 284)7. Gökçen, toplumunun modernleşme sürecinde eriştiği aşamayı temsil etmektedir. Yeni rejim, onun şahsında kendi modernizasyon sürecinin başarısını görmektedir Çünkü kadınları her meslekte görmek önemli bir ilerlemecilik göstergesidir. Atatürk için de bu durum kıymetlidir. Milli mücadelede kadın ve erkekler birlikte savaşarak bu vatanı kurmuşlardır. Ama henüz kadınların askerlik mesleğine girmesi ile ilgili bir yasal düzenleme yoktur. Sabiha Gökçen askerlik konusundaki düşüncelerini bir Cumhuriyet bayramı kutlamasında Atatürk'e açıklar. Atatürk konuyu dönemin Genel Kurmay Başkanı Fevzi Çakmak ile konuşmasını söyler. Bunun üzerine Sabiha Gökçen, Çakmak'a gider ve kendisinin asker olarak yasal bir düzenleme ile bu mesleği yapamadığını ifade eder. Gökçen, kadınların da resmen asker olmalarını sağlayacak bir izin ve yasa düzenlemesi talebinde bulunur. Fevzi Çakmak ise "Bunu benden istemeyin. Çünkü ben kızlar1mızın kadınlarımızın asker olmalarına asla razı değilim. Bir milletin var olması, o milletin kadınlarının yaşaması ile mümkün olur ancak" diye cevap verir (Verel, 2000, s. 227). Sabiha Gökçen bu sözlerin üzerine meseleyi

\footnotetext{
${ }^{7}$ Aslında Türk kadınlarının askerlikle ilişkisi daha öncesine dayanmaktadır. Birinci Dünya Savaşı sırasında kadınların Osmanlı ordusuna katılmaları için özel bir tabur kurulmuştur (Toprak, 2015, ss. 7-9). Ancak Sabiha Gökçen, cephenin gerisindeki yardımcı hizmetlerle sınırlı kalmayan, aktif olarak savaşan bir kadın olarak geçmiş deneyimlerin ötesinde bir anlam taşımaktadır.
} 
burada kapatır ve bütün heyecanının yıkıldığını söyler, o günden sonra bu konuyu hiç açmamıştır. Bu dönemden sonra da kadınların orduya alınması ile ilgili bir düzenleme olmaz. Anılarında kendi durumunu yasasız bir hal olarak tanımlar. Ona göre Atatürk'ün hatırı için bu mesleği sürdürebilmektedir. Bulunduğu durumdan çok rahatsızlık duyduğunu da ifade eder. 1940 yılında ordudan ayrılan Sabiha Gökçen, sonrasında Türk kuşunda çalışmaya devam eder (Verel, 2000, s. 312). Sabiha Gökçen, bu talebi ile ilk defa kurucu erkekler ile itilafa düşmüştür. Kadınlar adına yapmış olduğu talep ret edilmiştir (Altınay, 2015, s. 278). Ancak Cumhuriyet rejiminin ordu içerisine kadın asker almak gibi bir planı zaten yoktur. Aslına bakılırsa Sabiha Gökçen'in ordu içerisindeki durumunun sürekli olması beklenmez, zira yalnızca erkeklerin silah altına alınabileceğine dair kanunlar yürürlüktedir (Altınay, 2013, s. 277). Hatta daha önceleri, 1927 y1lında kadınlar seçme ve seçilme hakkı istediklerinde -ki bu talep yerel seçimler için 1930'da, genel seçimler için 1934'te tanınmıştı- buna karşı çıkan dönemin tek partisinin genel sekreteri Recep Peker, bu hakkı elde edebilmek için askerlik yapılması gerektiğini hatırlatacaktı (Toprak, 2015, s. 467). Muhtemelen, bu durumun imkansız ve uygunsuz olduğunu düşünmekteydi. Rejimin yapmak istediği toplumsal cinsiyet temelli eşitsizliklerle mücadele etmek ve kadınları her alanda özgür ve bağımsız bireyler yapmak değil, kadının elde ettiği yeni roller üzerinden, toplumun geleneksellikten ne kadar çıktığını tüm dünyaya 'göstermek'tir. Bu tespit, o dönemde toplumsal cinsiyet eşitliği anlamında hiç aşama kaydedilmemiş olduğu anlamına gelmemektedir. Aksine, 1930'ların Türkiye'sinde kad1nın toplumsal hayattaki rolüne ilişkin kimi iyileşmeler yaşanmış, öğretmenlik başta olmak üzere kimi profesyonel mesleklere, aslında toplumsal cinsiyet temelli önyargıların da etkisi ile kadınlar teşvik edilmiştir. Ancak sınırlar çizilidir. Dolayısıyla kadınlar toplumsal alanda sembolleştirilerek ve birer gösterge olarak konumlandırılmakta, bireysel tercihleri ve gelişmeleri sınırlandırılmaktadır. Kadınlar kamusal alanda edindikleri haklar ile daha görünür kılınırken, pek çok alanda ailenin devamlılığı gibi geleneksel rollerinin sürdürürken denetlenmeye devam edilmişlerdir (Durakbaşa, 1998, s. 31).

Sabiha Gökçen, ilericiliği temsil eden kadın semboller içerisinde tek bir örnektir ve öyle kalması beklenir. Onun asker kadın olarak Cumhuriyetin modernliğini temsil ettiğini, askeri alanda kadın subayların alımının 
1955'e kadar gerçekleşmediğini ve kanun değişikliğinin ancak 1963 y1lında olduğunu görmekteyiz. Tekrar ve bir daha değişmeksizin kadınların subay yetiştiren askeri okullara kabulü ise ancak 1990'larda gerçekleşmiştir (Altınay, 2013, s. 279). Sabiha Gökçen gönülden bağlı olduğu askeri havacılığı, meslek olarak yapamamıştır ancak dünyada askeri bir harekâta katılan ilk kadın savaş pilotudur. Sabiha Gökçen, Dersim harekâtı sonrasında Kore Savaşına da katılmak istemiştir. Ancak bu isteği, BM'nin kadınların cephe gerisinde tutulması kararı nedeni ile reddedilmiştir.

Sabiha Gökçen başarıları ile sadece kişisel gayreti ve çabasını değil aynı zamanda Türk kadının başarısını da temsil etmektedir. Atatürk bu başarıları modernleşmiş ulusun az zamanda nasıl çok işler başarabildiğinin göstergesi olarak dosta düşmana ispatlamaya çabalar. Atatürk, Sabiha Gökçen'i asker olarak üniforması ve silahı ile yeni devletin geldiği noktayı gösterdiği ve diğer kadınlardan farklı olarak geleceği simgelediğini düşünerek sıklıkla toplantılara çağırır ve onun yanında bulunmasını ister. Sabiha Gökçen zaman zaman gösteri uçuşları ile de ulus devletin gücünün simgesi olur. Bunlardan biri de Hatay meselesinin gündemde olduğu bir dönemde Fransızlar ile yapılan toplantılardır. Atatürk'ün Sabiha Gökçen'in de hazır bulunmasını istemesi bir güç nişanı olarak Türk gencinin vatanı için neler yapabileceğini gösterir. Genç Türk kadın savaş pilotu büyük bir adanmışlık ile milli mücadele döneminde olduğu gibi vatan savunmasında olduğunu bu şekilde gösterir. ${ }^{8}$

Yine Balkan Paktı'nın imzalanması sürecinde de Sabiha Gökçen'den uçakla bir Balkan turu yapması istenir. Sabiha Gökçen'in uçağı ile bu geziyi yapması ilerlemiş ulusun bir timsali gibidir. Bu uçuş öncesi Atatürk, Sabiha Gökçen'e “Erkek pilotların bile kolay kabul edemeyeceği bir teklif bu. Hayır dersen bir şey kaybetmeyiz neticede sen bir genç kızsın" der. Ancak Sabiha Gökçen, hayran olduğu ve her şeyini borçlu olduğu

\footnotetext{
${ }^{8}$ Sabiha Gökçen'in Atatürk'ün yanında üniforması ile bulunduğunu, dönemin basınında yapılan haberlerde de yer almıştır. Örneğin, 6 Temmuz 1937 Ulus gazetesinde bir "Kahraman Tayyarecimiz" haberi ile Sabiha Gökçen'in fotoğrafı bulunmaktadır.http://www.gecmisgazete.com/haber/kahraman-teyyarecimiz11574?tamBoyut Sabiha Gökçen'e başarılarından dolayı verilen madalya töreni haber yapılmıştır. "Tayyareci Sabiha Gökçene merasimle madalya verildi"29 Mays 1937, Cumhuriyet Gazetesi. http://www.gecmisgazete.com/haber/tayyareci-sabiha-gokcene-merasimle-madalya verildi?page=6,
} 
Atatürk'ün bu teklifini geri çevirmez. Bütün Balkan ülkelerini gezer ve gittiği yerlerde sevinçle karşılanır, haberleri yapılır. Sabiha Gökçen, barışın elçisi olduğunu Atatürk'ün yurtta barış dünyada barış ifadesi ile dile getirir (Verel, 2000, s. 269). Altınay'a göre Sabiha Gökçen'in Balkan ülkelerini ziyaretinde temelde barış mesajı verilmesine karşılık, aslında barışın savaşmaktan geçtiğinin de iması vardır. Bu ülke ziyaretlerinde askeri üniforma giymesi onun barış bile olsa savaş kaçınılmazdır vurgusunu gösterir. Militarizm arttıkça toplumsal ilerlemenin devamı sağlanacaktır (2013, s. 289). Gerçekten de büyük savaşlardan çıkmış bir ulus için barışın devamlılığının askeri alan başta olmak üzere her alanda ilerleme ile mümkün olduğu inancı hâkimdir. Bu nedenle barış için savaşılabileceğini bu gezi ile Sabiha Gökçen göstermiştir.

Sabiha Gökçen yaşamı boyunca Atatürk ile geçirdiği dönemi gerçek anlamda ömrü olarak tanımlamıştır. Örneğin, Atatürk'ün ölümü sonrası hayatına, anılarında çok yer vermez, hatta bir tür suskunluk dönemidir onun için bu dönem. Bu nedenle onun gözünde Atatürk hayranlık duyulacak bir önder ve Türk kadının geldiği konum ve başarıların da yegâne sebebidir. Türk kadını, Mustafa Kemal'in desteği ve isteği sayesinde özgürleşmiştir (Altınay, 2013, s. 279). Dolayısıyla kadınlar ulus-devlet oluşumlarında, özgürleştirici bir (erkek) lideri özgürlüklerini mümkün kılan, onun koşullarını ve nedenlerini oluşturan unsur olarak tanımlamaktadırlar.

\section{Sonuç}

Kadınların toplumsal hayatta görünürlük kazanmaları genç Cumhuriyet ve Cumhuriyet elitleri için kurdukları rejimin önceki dönemden farkını göstermektedir. Cumhuriyetin ilerlemeci, modern ve gelişmişliğinin ispatı, rejimin meşruiyetinin sağlanması açısından önemlidir. Kadının toplumsal hayatta artan görünürlüğü bu nedenle gurur duyulacak bir şeydir. ${ }^{9}$ Cumhuriyet rejimi yeni modern birey olan Cumhuriyet kadınını

\footnotetext{
9 1908'den başlayan ve Cumhuriyetten sonra iyice artan kadının bu kamusal görünürlüğ̈ünün dönemin gazete ve dergilerinden derlenmiş çok sayıda örneği için bkz. Zafer Toprak, Türkiye'de Kadın Özgürlüğü ve Feminizm (1908-1935).
} 
düzenlenen kamusal gösterilerde sıklıkla göstermektedir. ${ }^{10} 1930$ 'ların ortalarına gelindiğinde kadınlar modernleşmenin öznesi olurken, Sabiha Gökçen örneğinde görüldüğü üzere, kadının toplumdaki yerinin ne kadarilerlediğini gösteren bir nesne haline de getirilmişti. Kadınlar, okullar, hastaneler, kamusal alanların yanı sıra, aynı şekilde balolar, resmi törenler ve toplantılarda erkekler ile birlikte yer almakta idiler. Bütün bunlardan farklı olarak, askeri üniformalı bir kadının boy göstermesi ise eski ve yeni rejim arasındaki farkı iyice belirginleştirmiştir. Özellikle, Osmanlı geleneğine baktığımızda askerlik, herkesin dâhil olabileceği bir alan değildir. Toplumda ötekiler, eksik, az veya kusurlu olanlar bu alandan dışlanmaktayd.. ${ }^{11}$

Modernleşme süreçlerinde kadınlar, ilericilik dışında, ulus-devletlerin oluşumunda milli birliği şekillendiren bir yapı taşıdır. Kadınlar milliyetçiliğin oluşmasında birer aracıdır (Davis, 2003, s. 21). Bu nedenle Sabiha Gökçen'in kamusal görünürlügü de milli şuurun yaratılması için etkili olmuştur. Bir kadın asker, vatan savunmasını her şeyden öte hatta bir kadın olarak sahip olduğu sorumluluklardan da fazla savunarak üzerine düşeni yerine getirmiştir. Diğer taraftan ise Cumhuriyet sonrası kamusal görünürlük sınırlıdır, semboliktir. Kadından beklenen daha önce Fevzi Çakmak'ın orduya kadınların alınmaması gerektiği söylemlerinde de öne çıtığı gibi, milletin evlatlarının yetiştirilmesi, ailenin korunması ve verilen modern kadınlık görevlerini yerine getirirken kamusal görünürlüklerini de devam ettirmeleridir. Sabiha Gökçen de bu anlamda havacılığa yönlendirilmiş ve başarılı bir asker profili çizmiş dahi olsa bundan sonraki süreçte kadınların hakları bağlamında ciddi bir ilerleme yaratamamıştır. Kendi hayat çizgisine de baktığımızda, Atatürk'ün ona verdiği güveni

\footnotetext{
${ }^{10}$ Kadınları ile ilgili gösterilere örnek olarak, Leyla Kırkpınar'ın "Türkiye'de Toplumsal Değişme Sürecinde Kadın" başııkı yazısına bakılabilir. Bölümde verilen resimlerde çeşitli arşivlerden alınmış fotoğraflara yer verilmiştir. Bu fotoğraflarda 19 Mayıs kutlamalarına katılan kadın öğrenciler resmedilmiştir. Bu konuda benzer resimler için bkz Ayşe Durakbaşa'nın "Cumhuriyet Döneminde Modern Kadın ve Erkek Kimliklerinin Oluşumu: Kemalist Kadın Kimliği ve Münevver Erkekler" makalesine de bakılabilir

${ }^{11}$ Bu ayrıcalık ile ilgili durum askere alnımada değildir. Kuşkusuz burada bir ayrım söz konusu değildir. Hatta uzun süre savaşlar askerliği sıradan halk için büyük bir külfete dönüştürmüştür. Burada üzerinde durulan askerlik mesleğidir. Osmanlı düzeni içerisinde askerlik, sadece hâkim olan millete değil, aynı zamanda hâkim olan cinse, yani erkeğe ait, "maskülen" bir alandır. Aynı konumun Cumhuriyet ile birlikte farklılaşabileceği gösterilmek istenmiştir. Ancak hala askerliğin bir erkek alanı olduğunu gösteren bir örnek için bkz. http://www.hurriyetdailynews.com/being-a-gay-man-in-the-turkish-military.aspx?page $\mid D=238 \& n I D=70814 \&$ News Cat $I D=339$
} 
boşa çıkarmayarak başarılar elde etmesine karşılık, Atatürk sonrası yaşaminda sessizliğe bürünmüştür. Gökçen, Kemalist modernleşme projesine öylesine inanmış bir Türk kızıdır ki, Cumhuriyet'in ona sunduğu fırsatlara ihanet etmemiş ve bu fırsatları sonuna kadar kullanmaya çalışırken kendi kimliğinden de vazgeçerek örnek olmuştur (Ağduk, 2013, s. 322). Tekeli'nin tasvir ettiği hali ile "kurtulmuş kadınlar" arasında olduğu söylenebilir. Ona göre, Cumhuriyet'in sadık anneleri olarak kadınlar, Kemalizm'i feminizme tercih etmiş, bu anlamda İslami düzen yerine laik düzenin devamlılı̆̆ının önemine odaklanmışlardır. Cumhuriyete ve Atatürk'e duydukları bağlılık, verdiği haklar için minnettarlığa dönüşürken, ataerkil ilişkilerin eleştirisini yapmamışlardır (Tekeli, 2011, s.29-30). Oysa, Türkiye Cumhuriyeti'nin batılılaşma çabası, Türk kadınına yönelik toplumsal alanda eşitsizliği ortadan kaldırmayı öngören politikalar bir yana kadına belirli haklar tanırken, özellikle kadınlar arasında da bir eşitsizlik yaratmıştır. Bu tabakalaşmanın gerçekleştiği alanlardan ilki modernleşen, şehirli, okuyan ve Türk inkılabına sahip çıkan kadınları ile çevrede olan ve bu süreçleri uzaktan takip eden, bu sürece dâhil olmayan kadınları arasındadır. Modernleşme projesinin etkisini ilk bahsi geçen kadınlar daha çok hissederken, kırsalda, feodal ilişkilerin dâhilindeki kadınlar bu değişimi yakalayamamışlardır. ${ }^{12}$ Cumhuriyetin modernleşmeci kadınları için ise asıl sorun, merkezin dışındaki bu kadınlar yeterince eğitilmemesinden kaynaklanmaktadır. Ancak kurtarılmış kadınların böyle bir sorunu yoktur (Tekeli, 2011, s.30).

Sonuçta, bugünden bakıldığında Sabiha Gökçen'nin önemli bir sembol ve simge olduğu kabul edilebilir. Sabiha Gökçen bir kadın pilot olarak önüne çıkan engellere rağmen, toplumun dayattığı kuralların dışında bir profil çizmiş başarılı bir örnektir (Balcı ve Karadeniz, 2018, s.6). Bu başarı ulus devletleşme ile birlikte gerçekleşen modernleşme projesinin başarısıdır. Dünyanın pek çok modernleşme projesinde olduğu gibi ulus-devletleşme ile birlikte kadınların daha çok gösteren olarak öne çıkarılması

\footnotetext{
12 Modernleşmenin Türkiye'de merkezde kentli kadının yaşamında getirmiş olduğu değişime karşılık, kırsaldaki yaşamın içerisinde kadınlara müdahale etmediğini, hatta buralarda iktidar ilişkilerinin oluşturduğu feodal bağları güçlendirdiği düşüncesi ile ilgili çalışmalar için bkz: Ertürk, Yakın (2011). "Doğu Anadolu'da Modernleşme ve Kırsal Kadın", Selda Tuncer (2018). "Women and Public Space in Turkey" Gender, Modernity and the Urban Experience", Onur-Ince Hilal vd. (2009). "Customary Killings In Turkey And Turkish Modernization". Kandiyoti Deniz (2011). Ataerkil Örüntüler: Türk Toplumunda Erkek Egemenliğinin Çözümlenmesine Yönelik Notlar.
} 
tesadüf değildir (Altınay, 2013, s. 289). Sabiha Gökçen'in başarısı aynı zamanda Türk modernleşme projesinin kendiliğinden, başkalığından kaynaklanan bir özgünlügünün olduğunu gösterir. Neticede modernleşme projesinin yönü Batılılaşma ise Sabiha Gökçen sembolik de olsa Türk modernleşmesinin başkalığının göstergesi olmuştur. Savaş dışında, barış dönemlerinde bir kadının aktif olarak öne çıkması ise kadın hareketini hızlandırıcı bir yöne dönüştürülememiş, sadece sembolik bir anlam taş1makla kalmıştır. 


\title{
EXTENDED ABSTRACT
}

\section{An Assessment on Sabiha Gökçen as the Female Military Symbol of Turkish Modernisation}

\author{
Aysun Yaralı Akkaya \\ Van Yüzüncü Yıl University
}

Modernizing projects realize major transformations by intervening in social life. Within the traditional structures, transformation to being a society from congregation requires to break all of the connections with old ones which are dominated by primary relations and formed through mechanical solidarity and hand work production. Thus, new structures, networks and relationships are created while eliminating the traditional one. Turkish modernization has started with the last era of Tanzimat Reform with the aim of breaking the connections with the old, progressing and becoming Westernized. With Turkish modernization, new structures created in not only social structure but also cultural, social and political fields. These include the nation-state, modern citizenship, transformative reforms, a strong bureaucratic structure, a system compatible with secular society and modern law. While all citizens have equal rights in this westernization-based transformation, there was not differentiation from gender before the law. Republican reforms have realized the most rapid transformation in women's lives. In fact, starting from the period after the proclamation of the Tanzimat, women appear to be visible in the public sphere and form partnerships in order to become popular. This process is the most directed by the educated women members of upper-class palace families who are in touch with the West. These pioneering women also supported the new nation-state process. In the early years of the republic, the modernizing elites ensured women come into prominence and deemed they are the means of demonstrating the success of the reforms. The main issue to be emphasized here is that although women abided by the reforms and are loyal citizens, they are faced with constant limitations. When women were liberated or rescued, they were able to remain in a limited space that the new state offered them. Women's demands for 
equality, and their desire to be visible are carried out by measures that do not put the position of the nation-state established by men at risk. In this period, while the struggle for women's rights in the West started the debate on feminism, this struggle for Turkish women was carried out under the control of the nation-state and by the founding elites. Therefore, the demands of women including rights and equality strengthened by adhering to the basic principles and reforms of the Republic. The nation-state has created malleable citizens with its policies that control, inspect and discipline the bodies not only on women but on the whole society.

From this point of view, all nation-state projects have created a new nation that is fed by both the modernization and the nationalism ideology. Meanwhile, women either become effective actors of nation projects or heroic symbols of the nation-state. Women tend to be in contact with the founding elites of nation states to take advantage of the opportunities offered by the modernization process. Sabiha Gökçen, included in this study, is a symbolized name. Sabiha Gökçen, like other pioneering women of the era, symbolizes the stage of the Turkish women and what modernized state brought. With the proclamation of the Republic, women show up in urban life, social life and in working life along with men and had right to elect and be elected before many other countries. However, the expectation from these projects carried out by the government is that women fulfill their domestic roles while maintaining their presence in the public sphere. The areas where they are already employed are professions suitable for female gender. In this process, Sabiha Gökçen is the sign to how state of Turkey and the young Republic become integrated with West. She preferred aviation, not yet known, with her education abide by basic principles of republic. On the other hand, she was the first woman to attend a military operation. The essence of soldiery is a masculine place from the traditional periods. Because of their physical characteristics, men have the most influence in this area. On the other hand, women should be excluded from such areas with their elegant, delicate and sensitive natures. Sabiha Gökçen is one of the women who have received the same training with men and who have the right to work in the same way. Sabiha Gökçen has always expressed that she sticks to both the Atatürk and the nation-state and has accepted herself as the liberating leader who freed women. Turkish woman's effort, desire and success are symbolized in her life. Sabiha 
Gökçen's successes are also frequently highlighted and it shows the hope and determination for the generations of the Republic. Therefore, she became a symbolic name of the progress of the Republic. What makes her symbolic is the fact that she encountered limitations of being a woman. It is often reminded for the extent to which the Turkish girl's chastity, honor, or dignity of the Turkish girl has an inclusive meaning. Her demands in masculine field meet control of masculine identities or obstacle. What is desired from her is that contenting with what she gets and being grateful for the opportunities brought by the achievements of the Republic. In other words, the women of the Republic should sacrifice when necessary and be able to give up from herself for the continuity of the Republic. Women's maternity and raising young generations who can carry nationstate to to the should be the biggest tasks of women. Sabiha Gökçen is depicted as the best stage for women in the new nation-state table. Thus, she maintains the goal of "Westernism" of Turkish modernization and even points to a further stage than it. For this reason, while Turkish modernization was trying to achieve the goal set on the basis of Westernism, the reforms that freed women were tried to be put forward with symbolic names.

\section{Kaynakça / References}

Ağaoğlu, A. (1998). Ölmeye yatmak. Ankara: Yapı Kredi Yayınları.

Ağduk, M. (2013). Cumhuriyet'in asil kızlarından '90'ların türk kızlarına 1990'larda bir "Türk kızı": Tansu Çiller, A.G. Altınay (Der.), Vatan Millet Kadınlar, s.297-323. İstanbul: İletişim Yayınları

Altınay, A. G. (2013). Ordu-millet- kadınlar: Dünyanın ilk kadın savaş pilotu sabiha gökçen A. G. Altınay (Der.), Vatan Millet Kadınlar, s. 261-295. İstanbul: İletişim Yayınları

Arat, Y. (1998). Türkiye'de modernleşme projesi ve kadınlar. Türkiye'de Modernleşme ve Ulusal Kimlik, s.82-99. S.Bozdoğan ve R. Kasaba (Edt.). İstanbul: Tarih Vakfı Yayınları.

Arman, A. (2014, 23 August). Being a gay man in the turkish military.Hurriyet. Accessed on 7 June 2015 from http://www.hurriyetdailynews.com/being-a-gay-man-in-the-turkish-military.aspx?pageID $=238 \& n I D=70814 \&$ NewsCatID $=339$, 
Balc1, M. ve Karadeniz, Y. (2018). Cumhuriyet modernleşmesinin genç kadın pilotu: Sabiha Gökçen. Marmara Üniversitesi Kadın ve Toplumsal Cinsiyet Araştırmaları Dergisi, 2 (1), 1-7.

Best, S. ve Kellner, D. (1998). Postmodern teori "eleştirel soruşturmalar", (M. Küçük, Çev.), İstanbul: Ayrıntı Yayınları.

Çiçek, A. C., Aydın, S. ve Yağcı, B. (2015). Modernleşme sürecinde kadın: Osmanlı dönemi üzerine bir inceleme. Kafkas Üniversitesi İktisadi ve İdari Bilimler Fakültesi Dergisi, 6 (9), 269-284.

Çiğdem, A. (2002). Türk batılılaşması'nı açıklayıcı bir kavram: Türk başkalığ 1 batılılaşma, modernite ve modernizasyon, Modern Türkiye'de Siyasi Düşünce, Cilt. 3, s. 62-81. İstanbul: İletişim Yayınları.

Durakbaşa, A. (1998). Cumhuriyet döneminde modern kadın ve erkek kimliklerinin oluşumu: Kemalist kadın kimliği ve münevver erkekler. 75 Yılda Kadınlar ve Erkekler içinde, s.29-50. A. B. Hacımirzaoğlu (Edt.). İstanbul: Tarih Vakfı Yayınları.

Ertürk, Y. (2011). Doğu Anadolu' da modernleşme ve kırsal kadın, 1980'ler Türkiyesi'nde Kadın Bakış Açısından Kadınlar, s.177-187. Ş.Tekeli (Haz.). İstanbul: İletişim Yayınları.

Giddens, A. (1994). Modernliğin sonuçları. (E. Kurşdil, Çev.). İstanbul: Ayrintı Yayınları.

Giddens, A. (2008). Sosyoloji. İstanbul: Kırmızı Yayınları.

Göle, N. (1991). Modern mahrem medeniyet ve örtünme. İstanbul:Metis Yayınları.

İnce, H. O. Yaralı, A. ve Özsel, D.(2009). Customary killings in Turkey and Turkish modernization. Middle Eastern Studies, 45 (4), 537-551.

İrem, N. (1999). Muhafazakar modernlik, diğer batı ve Türkiye'de Bergsonculuk. Toplum ve Bilim, 82, 141-178.

Jeanniere, A. (2000). Modernite nedir? Modernite Versus Postmodernite, M. Küçük(Der.), s. 95-107, Ankara: Vadi Yayınları.

Kahraman, H. B. (2002). Bir zihniyet, kurum ve kimlik kurucusu olarak batılılaşma. Modern Türkiye'de Siyasi Düşünce, Cilt. 3, s. 125-146. İstanbul: İletişim Yayınları.

Kandiyoti, D. (1997). Kurtulmuş ama özgürleşmiş mi? Türkiye örneği üzerine bazı düşünceler. Cariyeler, Bacılar, Yurttaşlar Kimlikler ve Toplumsal Dönüşümler. İstanbul:Metis Yayınları. 
Kandiyoti, D. (2011). Ataerkil örüntüler: Türk toplumunda erkek egemenliğinin çözümlenmesine yönelik notlar, 1980'ler Türkiyesi'inde Kadın Bakış Açısından Kadınlar, s. 327-341. Ş.Tekeli (Haz.). İstanbul: İletişim Yayınları.

Kaypak, Ş. (2014). Cumhuriyet dönemi modernleşme sürecinde değişen kadın kimliği, Uluslararası Medeniyet ve Kadın Kongresi (13-16 Ekim 2014). Halide Edip Adıvar'ın Ölümünün 50. Yıldönümü Anısına, A. G. Saygın ve M. Saygın (Yayına Haz.), ss. 33-66. Ankara: Atatürk Araştırma Merkezi Yayını.

Keyman, F. (2001). Şerif mardin toplumsal kuram ve Türk modernitesini anlamak. Doğu-Batı, 16, s. 9-29, Ankara: Doğu-Batı Yayınları.

Kırkpınar, L. (1998). Türkiye'de toplumsal değişim sürecinde kadın, 75 Yılda Kadınlar ve Erkekler, s.13-29, A. B. Hacımirzaoğlu (Edt.), İstanbul: Tarih Vakfı Yayınları.

Mardin, Ş. ( 1991). Türk modernleşmesi. İstanbul: İletişim Yayınları.

Mardin, Ş. (2002). Türk modernleşmesi makaleler. 4. M. Türköne -T. Önder (Der.). İstanbul: İletişim Yayınları.

Mutman, M. (2004). Şarkiyatçllı/Oryantalizm. Modernleşme ve BatıcllıModern Türkiye'de Siyasi Düşünce, 3, s. 189- 217. İstanbul: İletişim Yayınları.

Sancar, S. (2014). Türk modernleşmesinin cinsiyeti erkekler devlet, kadınlar aile kurar. İstanbul: İletişim Yayınları.

Şaylan, G. (2002). Postmodernizm. Ankara: İmge Yayınları.

Tekeli, İ. (2002). Türkiye'de siyasal düşüncenin gelişimi konusunda bir üstü anlatı. Modernleşme ve Batıcllı- Modern Türkiye'de Siyasi Düşünce, 3, s. 19- 42. İstanbul: İletişim Yayınları.

Tekeli, Ş. (2011). 1980'ler Türkiyesi'nde kadınlar, 1980'ler Türkiyesi'nde Kadın Bakış Açısından Kadınlar, s. 15-46. Ş.Tekeli (Haz.). İstanbul: İletişim Yayınları.

Toprak, Z. (2015). Türkiye'de kadın özgürlü̆̆̈̈ ve feminizm (1908-1935). İstanbul: Tarih Vakfı Yayınları.

Tuncer, S. (2018). Women and Public Space in Turkey Gender, Modernity and the Urban Experience, London. New York:I.B.Tauris.

Varel, O. (2000). Sabiha Gökçen Atatürk'le bir ömür. İstanbul:Altın Kitabevi. Yavuz, H.(1998). Batılılaşma değil, oryantalistleşme. Doğu-Batı, 2, s.115117. Ankara: Doğu-Batı Yayınları. 
Yuval-Davis, N. (2003). Cinsiyet ve millet. (Çev. A. Bektaş). İstanbul: İletişim Yayınları.

http://www.gecmisgazete.com/haber/kahraman-teyyarecimiz-11574?tamBoyut http://www.gecmisgazete.com/haber/tayyareci-sabiha-gokcene-merasimle-madalya verildi?page $=6$

\section{Kaynakça Bilgisi / Citation Information}

Akkaya, A.A.(2019). Türk modernleşmesinin kadın-asker sembolü Sabiha Gökçen üzerine bir değerlendirme. OPUS-Uluslararası Toplum Araştırmaları Dergisi, 11(18), 2433-2462. DOI: 10.26466/opus. 532089 